\title{
Review
}

\section{Years of European Philosophy Since the Great War: Crisis and Reconfigurations}

Matthew Sharpe, Rory Jeffs and Jack Reynolds (Eds.)

Springer, London, 2017, ix + 288pp

ISBN: 978-3-319-50360-8

'This war is not the end, but rather the beginning of violence', observed Ernst Jünger (1922: 77). He was not alone in seeing in WWI the inauguration of a new era. In a remark cited at the outset of this volume, Hannah Arendt (1951: 267) noted that August 1914 'touched off a chain reaction in which we have been caught ever since and which nobody seems to able to stop'. Historians looking back at the 'short twentieth century' of total mobilisation, ideological conflict and mass violence have recently given credence to the view that WWI began a conflagration that continued long past 1918. Yet, while a vast literature exists on the legacy of the war in politics, art and literature, little has been said about it as a global conflict of ideas that altered philosophy. This collection, conceived at a conference occasioned by the centennial of 1914, seeks to fill that gap by viewing European philosophy through the lens of the war and the 'chain reaction' that followed.

The focus of this volume on WWI grants it unusual sharpness of purpose, especially given the broad terrain covered: phenomenology, psychoanalysis, Hegelianism and Marxism and less expected subjects such as neoliberalism and early analytical philosophy. Philosophers treated range from Hermann Cohen, Spengler and Russell to Hayek and contemporaries such as Badiou and Žižek. Most chapters avoid arid literature surveys, drawing instead upon close readings and intellectual history to expose the intensified interpenetration of politics and philosophical ideas after the war. The most interesting pursue narrow lines of argument against broader themes. These are arguably more convincing than the ambitious attempts to show that 'the world we live in today hearkens back in decisive ways to the European catastrophe of World War I' (p. 4), which at times elide the history of ideas and political history.

The book is split into five sections ordered along chronological and thematic lines, with the first two focusing on Germany. In his opener, William Altman argues that Weimar 'antimodernism' (p. 15) should be understood through the lens of German fury at the attribution of war guilt. Drawing on Christopher Clark's The Sleepwalkers (2012) he stresses the historical justification behind this anger and its effects on German intellectuals. The 'rage, betrayal, and despair' (p. 36) that resulted was the real wellspring of critiques of liberalism, progress and Western metaphysics made by Schmitt, Spengler, Heidegger and others. Appreciating these quotidian origins, Altman suggests, might have a deflationary effect that would allow philosophy to 'finally stop dreaming Weimar's dreams' (p. 34). It is not clear, though, how adjudicating Germany's historical responsibility for the war (or lack of it) through hindsight unavailable to Germans at the time helps us better interpret their thought. Altman ultimately makes a therapeutic case for contemporary philosophy jettisoning its 
Weimar syndrome to establish a truly 'post-post-war' (p. 27) thought; an interesting claim, but one that goes beyond the bounds of historical argument.

By contrast, at the beginning of the second part of the book on 'Weimar and its Shadows', Miguel Vatter's compelling 'Nationality, State and Global Constitutionalism in Hermann Cohen's Wartime Writings' makes a strong case for not jettisoning Weimar thought. Against the conventional picture of Cohen as responding to the war by reneging on his socialist and cosmopolitan commitments, Vatter shows a thinker developing a 'messianic politics' (p. 44) capable of navigating the transition from the nation-state to a confederation of socialist republics, rather than to a cosmopolitan 'disembedded capitalism'. This reinterpretation contests Derrida's influential reading that interprets Cohen's JudeoProtestantism as a 'globalised technoscientific rationalism'. Though revealing a figure far from the liberal nationalism of say, David Miller, Vatter uncovers a complex non-liberal cosmopolitanism that deserves to be reread alongside the contemporary politics of European integration.

Petra Brown and Julian Potter illustrate the starker transformations that took place after Cohen. In 'The Sons Destined to Murder Their Father: Crisis in Interwar Germany', Brown parses the generational shifts seen after the war in German philosophy (Cassirer, Heidegger), in jurisprudence (Kelsen, Schmitt), and especially in theology (Harnack, Barth), the last of these domains being the least investigated by scholars. Potter's 'The Spengler Connection' is equally ambitious, discussing how war encouraged critiques of reason among thinkers as different as Spengler, Weber, Heidegger, and Adorno. There are limits, however, to what affinities can evidence, especially given that Heidegger and Adorno were directly critical of Spengler. By contrast, in 'The Significance of World War I in Jan Patočka's Philosophy', Daniel Brennan has an easier job delineating a direct appropriation; the unexpected repurposing of Husserlian and Heideggerian phenomenology by Czech dissidents in the 70s and $80 \mathrm{~s}$.

The third part of this volume, on 'Intellectual Movements', is opened by Talia Morag's 'The Challenges of the Great War to Freud's Psychoanalysis', a precisely-argued revisionist explanation of Freud's introduction of the 'death instinct', showing that it was necessary to avoid a more radical reformulation of his theory in light of evidence from the traumatic dreams of war neurotics. Looser in historical argument is Geoff Boucher's 'The Long Shadow of Leninist Politics', which traces the Leninist model of revolutionary politics up to Žižek's reaffirmation of it in the guise of the 'Jacobin imaginary'. Boucher mounts a critique of Leninism's instrumentalisation of political action, noting its affinities with the ideals of the post-WWI militarist right; this is an intriguing hint at a history of the career on the left of Schmitt's counter-revolutionary concept of the political.

Rory Jeffs's 'Hegel in Dark Times' is a deft survey of the changing fortunes of Hegel's thought in the wake of war and revolution. Jeffs covers the well-trodden ground of the demise of British Hegelianism, but also looks at the less well-known defence of an idealist Hegel by Richard Kroner in the late 1920s, and compares this with Lukaçs and Kojève's famous usages. This is a cogent study of the 'very good historical reasons underlying...gaps and distortions' (p. 179). This reading avoids the national focus of much existing work on the topic. 
Opening the fourth part of the book, on 'Academic Philosophy', Sherah Bloor makes the opposite methodological gesture to Jeffs. On 'The Divide Between Philosophy and Enthusiasm', she employs a careful reading of Kant against Bertrand Russell's exaggerated criticisms of the 'enthusiasm' of German philosophy (as opposed to British 'scientific philosophy'). Similar terrain is traversed by Jack Reynolds in 'Philosophy and/or Politics?', which explores the origins of the analytic/continental divide. Against claims that the conflict had no impact on analytical philosophy, Reynolds makes a judicious set of judgments about the importance of developments before and after the war, from Russell to the Vienna Circle, He contrasts the trajectories of phenomenology and early analytic philosophy, as the latter began to associate the former with a covert and philosophically-illegitimate 'para-politics' ( $\mathrm{p}$. 219).

Reynolds points to a question implicit throughout this volume: how did the strife of the 'short twentieth century' alter definitions of philosophy and its relationship to politics? These essays show the war bringing philosophy into closer proximity to politics and ideological conflict. In the case of Spengler, this could even push an ideologue into the realm of philosophy. Conversely, the efforts of analytical philosophers to denounce the 'para-politics' of German idealism and avow their lack of politics are themselves uncovered as ideological. And finally, there is the evolution of popular ideologies, such as the currents collected under 'neoliberalism', canvassed by Damien Cahill in 'The Spectre of Collectivism'.

A second guiding question is whether these histories open the possibility of a postwar thought more appropriate to contemporary politics. Here the presentist essays that bookend the volume raise some potential problems. In the final chapter, Matthew Sharpe argues that philosophers ought to learn from intellectual historians and use a more careful understanding of WWI to historicise and minimise the 'counter-Enlightenment' that subsequently arose. But does the application of historical constructs and concepts such as 'counter-Enlightenment', as well as 'modernity' and 'totalitarianism' - used by John Rundell in his penultimate chapter as a guide for philosophical and historical practice not risk an idealism that obscures politics?

Another potential obstacle to this book altering our view of the past is the narrow focus on Europe. A collection of this kind unavoidably has its omissions and exclusions. But the impact of WWI on European philosophy cannot be told without appreciating the global scope of the conflict: in Turkey, Japan, India and elsewhere. The war prompted writers outside Europe to intensify critiques of European doctrines of reason, science and progress. Yet the non-Western world here appears as mostly external. There are other omissions: feminism, which is acknowledged, and secularisation, which is not.

Overall, however, this is a valuable and innovative contribution to the history of philosophy and political theory, edited in a way that avoids the shapelessness sometimes characteristic of surveys of twentieth-century philosophy. It reveals how philosophical lineages we take for granted bear the mark of the politics of the 'short twentieth century', and points to the relevance of this knowledge to political theorists today.

\section{References}

Arendt, H. (1951) The Origins of Totalitarianism. New York: Harcourt, 1951.

Clark, C. (2012) The Sleepwalkers: How Europe Went to War in 1914. London: Allen Lane. 
Gerwarth, R. (2016) The Vanquished: Why the First World War Failed to End. New York: Farrar, Straus and Giroux.

Jünger, E. (1922) Der Kampf als inneres Erlebnis. Berlin: E.S. Mittler \& Sohn.

Mazower, M. (1998) Dark Continent: Europe's Twentieth Century. London: Allen Lane.

Traverso, E. (2016) Fire and Blood: The European Civil War 1914-1945, Translated by D. Fernbach. London: Verso.

Waseem Yaqoob

University of Cambridge, UK

wy206@cam.ac.uk 